\title{
PENINGKATAN PRESTASI BELAJAR IPA FISIKA DENGAN MENGGUNAKAN PENDEKATAN PROBLEM POSSING DENGAN LATAR PEMBELAJARAN KOOPERATIF KELAS XI-ADM.A SMK NEGERI 1 NARMADA KABUPATEN LOMBOK BARAT TAHUN PELAJARAN 2016-2017
}

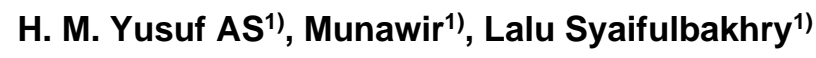 \\ 1)SMKN 1 Narmada, Kabupaten Lombok Barat, NTB, Indonesia \\ Corresponding author: H. M. Yusuf AS \\ E-mail : hajiyusuf64@gmail.com
}

Diterima 04 Oktober 2021, Direvisi 20 Oktober 2021, Disetujui 20 Oktober 2021

\begin{abstract}
ABSTRAK
Mayoritas guru IPA Fisika saat ini masih menggunakan cara-cara konvensional dalam pembelajaran IPA Fisika. Pendekatan pembelajaran ini dilakukan dengan metode ceramah dan tanya jawab. Kelebihan dan pendekatan ini adalah dapat mengajarkan materi yang relatif banyak dalam waktu yang singkat, tetapi pembelajaran ini memperlakukan siswa hanya sebagai objek sehingga siswa cenderung pasif dan hanya menerima pengetahuan dari gurunya saja. Pembelajaran konvensional hanya menyajikan materi IPA Fisika secara tekstual sehingga siswa kesulitan menerapkannya dalam kehidupan sehari-hari.Untuk meningkatkan kualitas pembelajaran IPA Fisika dibutuhkan pembelajaran yang merangsang siswa untuk melakukan pengamatan, penyelidikan serta mengolah informasi sehingga pada akhirnya siswa dapat memahami konsep secara bermakna. Pembelajaran yang menekankan keaktifan siswa dan berpusat pada siswa merupakan salah satu upaya yang dapat dilakukan untuk memperbaiki kualitas pembelajaran IPA Fisika.Salah satu proses pembelajaran yang sesuai adalah pembelajaran Cooperative Learning.Oleh karena itu penulis perlumelakukan penelitian tindakan dengan judul Peningkatan Prestasi Belajar IPA Fisika dengan Menerapkan Model Pembelajaran Cooperative Learning Kelas XI TKR SMK Negeri 1 Narmada Kab.Lombok Barat Tahun Pelajaran 2016-2017
\end{abstract}

Kata kunci: problem possing; cooperative learning; prestasi belajar.

\begin{abstract}
The majority of Physics Science teachers currently still use conventional methods in learning Science Physics. This learning approach is carried out using lecture and question and answer methods. The advantage of this approach is that it can teach relatively a lot of material in a short time, but this learning treats students only as objects so that students tend to be passive and only receive knowledge from the teacher. Conventional learning only presents physics science material textually so that students have difficulty applying it in everyday life. To improve the quality of science learning physics requires learning that stimulates students to observe, investigate and process information so that in the end students can understand concepts meaningfully. Learning that emphasizes student activity and is student-centered is one of the efforts that can be made to improve the quality of learning science physics. One of the appropriate learning processes is cooperative learning. Therefore, the authors need to conduct action research with the title Improving Physics Science Learning Achievement by Applying Cooperative Learning Model Class XI TKR SMK Negeri 1 Narmada Kab. Lombok Barat 2016-2017 Academic Year
\end{abstract}

Keywords: problem possing; cooperative learning; prestasi belajar.

\section{PENDAHULUAN}

Mata pelajaran fisika adalah salah satu mata pelajaran dalam rumpun sains. Hakikat sains adalah ilmu pengetahuan yang objek pengamatannya adalah alam dengan segala isinya termasuk bumi, tumbuhan, hewan, serta manusia. Sains adalah ilmu pengetahuan yang diperoleh denga nmenggunakan metodemetode berdasarkan observasi.
Soedjadi (2001: 1) menyatakan bahwa penyebab kesulitan memahami IPA Fisika dapat bersumber dalam diri siswa dan di luar diri siswa. Dalam diri siswa dapat berupa rendahnya motivasi, dan sikap terhadap IPA Fisika. Sedangkan dari luar diri siswa salah satunya dapat berupa metode pembelajaran yang kurang tepat dalam mengajarkan IPA Fisika. 
Mayoritas guru IPA Fisika saat ini masih menggunakan cara-cara konvensional dalam pembelajaran IPA Fisika. Pendekatan pembelajaran ini dilakukan dengan metode ceramah dan tanya jawab. Kelebihan dan pendekatan ini adalah dapat mengajarkan materi yang relatif banyak dalam waktu yang singkat, tetapi pembelajaran ini memperlakukan siswa hanya sebagai objek sehingga siswa cenderung pasif dan hanya menerima pengetahuan dari gurunya saja. Pembelajaran konvensional hanya menyajikan materi IPA Fisika secara tekstual sehingga siswa kesulitan menerapkannya dalam kehidupan sehari-hari.

Untuk meningkatkan kualitas pembelajaran IPA Fisika dibutuhkan pembelajaran yang merangsang siswa untuk melakukan pengamatan, penyelidikan serta mengolah informasi sehingga pada akhirnya siswa dapat memahami konsep secara bermakna. Pembelajaran yang menekankan keaktifan siswa dan berpusat pada siswa merupakan salah satu upaya yang dapat dilakukan untuk memperbaiki kualitas pembelajaran IPA Fisika.

Dari pengalaman pribadi penulis menjumpai sebagian besar siswa kelas XI TKR di SMK Negeri 1 Narmada Kabupaten Lombok Barat kesulitan menyelesaikan soal-soal yang berhubungan dengan IPA Fisika. Untuk mempermudah pemahaman siswa dan penanaman konsep IPA Fisika perlu dilakukan pembelajaran melalui pendekatan coopertive learning. Oleh karena itu penulis perlumelakukan penelitian tindakandengan judul : "Peningkatan Prestasi Belajar IPA Fisika dengan Menerapkan Model Pembelajaran Cooperative Learning Kelas XI TKRSMK Negeri 1 Narmada Kab.Lombok Barat Tahun Pelajaran 2016-2017 “.

\section{METODE PENELITIAN \\ Subjek Penelitian}

Subjek penelitian ini adalah peningkatan prestasi belajar IPA Fisika melalui penerapan pembelajaran Kooperatif (Cooperative Learning ) yang dilaksanakan di SMK Negeri 1 Narmada Khususnya kelas XI-TKR .

Berdasarkan hasil observasi yang penulis lakukan bahwa kelas XI TKR tingkat kemampuan siswa pada pelajaran IPA Fisika masih sangat rendah. Siswa merasa kesulitan dalam meningkatkan prestasinya sehingga siswa kurang respon terhadap pembelajaran IPA Fisika.

Penelitian ini merupakan penelitian tindakan kelas, yang dilakukan secara bertahap-tahap sampai mendapatkan hasil yang diinginkan. Jumlah dan namasiswa kelas XI TKR secara keseluruhan adalah 30 orang.

\section{Setting Penelitian}

PTK dilakukan di SMK Negeri 1 Narmada Kabupaten Lombok Barat Tahun Pelajaran 2016-2017. Kelas XI SMK Negeri 1 Narmada terdiri dari7 kelasdenganjurusan yang berbedadan jumlahsiswa pada masing masingkelasrelatifbesardibandingkandengan SMK lainnya yang ada di wilayah Kabupaten Lombok Barat. PTK dilakukan pada siswakelas XI TKR dengan jumlah 30 orang.

\section{Rancangan Penelitian}

Tindakan dilaksanakan dalam 3 siklus. Kegiatan dilaksanakan dalam semester Genaptahun pelajaran 2016-2017. Lama penelitian 6 pekan efektif dilaksanakan mulai tanggal 03 September 2016 sampai dengan 08 Oktober 2016.

\section{Variabel Penelitian}

Dalam penelitian tindakan kelas ini variabel yang diteliti adalah peningkatan prestasibelajar IPA Fisika siswa kelas XI TKR SMK Negeri 1 Narmada Tahun Pelajaran 20162017.

Variabel tersebut dapat dituliskan kembali sebagai berikut :

$\begin{array}{ll}\text { Variabel } & \text { Peningkatan prestasi } \\ \text { Harapan } & \text { belajar IPA Fisika kelas } \\ \text { Variabel } & \begin{array}{l}\text { XI TKR SMK Negeri 1 } \\ \text { Narmada }\end{array} \\ \text { Tindakan : } & \begin{array}{l}\text { Penerapan metode } \\ \text { pembelajaran } \\ \text { kooperatif }\end{array} \\ & \text { (Cooperative Learning) }\end{array}$

Adapun indikator yang diteliti dalam

variabel harapan terdiri dari :

1. Kemampuan Siswa dalam pembelajaran IPA Fisika

2. Kemampuan siswa dalam pembelajaran IPA Fisika melalui penerapan model pembelajaran kooperatif (Cooperative learning)

3. Keefektifan model pembelajaran kooperatif (Cooperative learning ) dalam meningkatkan prestasi belajar IPA Fisika siswa

Sedangkan variabel tindakan memiliki indikator sebagai berikut :

1. Tingkat kualitas perencanaan

2. Kualitas perangkat observasi

3. Kualitas operasional tindakan

4. Kesesuaian perencanaan dengan tindakan kelas

5. Kesesuaian teknik yang digunakan dalam meningkatkan prestasi belajar siswa

6. Tingkat efektifitas pelaksanaan pembelajaran kooperatif (Cooperative Learning) 
7. Kemampuan siswa dan guru menerapkan metode pembelajaran kooperatif (Cooperative Learning)

\section{Sumber dan Teknik Pengumpulan Data}

1. Sumber Data.

Sumber data dalam penelitian ini berasal dari dua sumber yaitu :

$\begin{array}{lll}1 \text { Siswa } \quad \text { : } & \text { Diperoleh data } \\ & \text { tentang peningkatan } \\ & \text { prestasipembelajaran } \\ & \text { IPA Fisika. data } \\ & \text { : } & \text { Diperoleh } \\ & \text { tentang } \\ & \text { efektifitaspenerapan } \\ & \text { pembelajaran } \\ & \text { kooperatif } \\ & (\text { Cooperative } \\ & \text { Learning) }\end{array}$

2. Teknik Pengumpulan Data :

Dalam pengumpulan data teknik yang digunakan adalah menggunakan observasi dan tes.

\section{Indikator Keberhasilan}

Penelitian tindakan kelas yang dilaksanakan dalam tiga siklus dianggap sudah berhasil apabila terjadi peningkatan prestasibelajarIPA Fisika siswamencapai $85 \%$ siswakelas XI TKR ( kelas yang diteliti) telah mencapai ketuntasan dengan nilai rata rata 75.Jika peningkatan tersebut dapat dicapai pada tahap siklus 1 dan 2,maka siklus selanjutnya tidak akan dilaksanakan karena tindakan yang dilakukan sudah dinilai efektif sesuai dengan harapan dalam kurikulum tingkat satuan pendidikan ( KTSP ).

\section{Teknik Analisis Data}

Dalam analisis data teknik yang digunakan adalah ;

1. Kuantitatif

Analisis ini digunakan untuk menghitung besarnya peningkatan prestasi siswa dalam pembelajaran IPA Fisika dengan menggunakan prosentase (\%).

\section{Kualitatif}

Teknik analisis ini digunakan untuk memberikan gambaran hasil penelitian secara; reduksi data, sajian deskriptif, dan penarikan simpulan.

\section{HASIL DAN PEMBAHASAN \\ Analisis Hasil Kegiatan}

Setelah dilakukan tindakan pada siklus 1 , siklus 2 dan siklus 3 menunjukkan hasil sebagai berikut:
Tabel 1. Analisis Hasil Kegiatan.

\begin{tabular}{|c|c|c|c|}
\hline & $\begin{array}{c}\text { Skor } \\
\text { sebelum }\end{array}$ & $\begin{array}{c}\text { Skor } \\
\text { setelah }\end{array}$ & $\begin{array}{c}\text { Skor } \\
\text { setelah }\end{array}$ \\
\hline & Tindakan & $\begin{array}{c}\text { Tindakan } \\
1\end{array}$ & $\begin{array}{c}\text { Tindakan } \\
2 \\
\end{array}$ \\
\hline & Siklus 1 & Siklus 2 & Siklus 3 \\
\hline Jumlah skor & 1135 & 2070 & 2263 \\
\hline $\begin{array}{l}\text { Skor Maksimum } \\
\text { Individu }\end{array}$ & 100 & 100 & 100 \\
\hline $\begin{array}{l}\text { Skor Maksimum } \\
\text { Kelas }\end{array}$ & 3000 & 3000 & 3000 \\
\hline Jml siswa yg tuntas & 8orang & 22orang & 28orang \\
\hline $\begin{array}{l}\text { Jml siswa yg belum } \\
\text { tuntas }\end{array}$ & 22orang & 8orang & 2orang \\
\hline Nilai rata-rata & 37,83 & 69 & 75,43 \\
\hline Ketuntasanklasikal & $26,67 \%$ & $73,33 \%$ & $93,33 \%$ \\
\hline
\end{tabular}

\section{Analisis Data Deskriptif Kuantitatif}

1. Pencapaian Prestasi belajar siswa kelas $X I$ TKR sebelum diberi tindakan

$$
=\frac{1135}{3000} \times 100=37,83
$$

2. Pencapaian prestasi siswa kelas XI TKR setelah diberi tindakan pengelompokan siswa berdasarkan nomor panggilan (acak berdasarkan tempat duduk )

$$
=\frac{2070}{3000} \times 100=69
$$

3. Pencapaian prestasi siswa kelas XI TKR setelah diberi tindakan pengelompokan siswa berdasarkan kemampuan akademik

$$
=\frac{2263}{3000} \times 100=75,43
$$

Dari hasil analisis tersebut dapat disimpulkan bahwa

1. Terjadi peningkatan prestasi setelah diberi tindakanyaitu 37,83 menjadi 69 ada kenaikan sebesar $=37,14$

2. Dari sebelum tindakan ( siklus 1 ) dan setelah tindakan sampai dengan (siklus 3 ) 37,83 menjadi 69 , dan dari ( siklus 2 ) ke ( siklus 3 ) juga ada peningkatan sebanyak $75,43-69=6,43$.

3. Rata - rata siswa sebelum diberi tindakandari 26,67 \% menjadi93,33\%.

Dari tindakan siklus 2 dan setelah tindakan( siklus 3 ) 69 menjadi 75,43 berarti ada peningkatan prestasi sebanyak 75,43-69= 6,43 .

\section{SIMPULAN DAN SARAN}

Hasil kegiatan pembelajaran yang telah dilakukan selama tiga siklus, dan berdasarkan seluruh pembahasan serta analisis yang telah dilakukan dapat disimpulkan sebagai berikut : 1) Pembelajaran dengan menerapkan pembelajaran Cooperative Learning mempunyai dampak positif dalam meningkatkan prestasi belajar IPA Fisikasiswa 
kelas XI TKR di SMK Negeri 1 Narmada yang ditandai dengan peningkatan prestasi belajar siswa dalam setiap siklus, yaitu siklus I $(37,83)$, siklus II ( 69$)$, dan siklus III $(75,43) ; 2)$ Penerapan model pembelajaran Cooperative Learning mempunyai pengaruh positif, yaitu dapat meningkatkan motivasi belajar siswa; 3) Penerapan model pembelajaran Cooperative Learning efektif untukmeningkatkan kembali materi ajar yang telah diterima siswa selama ini, sehingga mereka merasa siap untuk menghadapi pelajaran berikutnya.

Adapun saran yang disampaikan saran sebagai berikut 1) Untuk melaksanakan pembelajaran memerlukan persiapan yang cukup matang, sehingga guru harus mampu menentukan atau memilih topik yang benarbenar bisa diterapkan dengan pembelajaran Cooperative Learningagar diperoleh hasil yang optimal; 2) Dalam rangka meningkatkan prestasi belajar siswa, guru hendaknya lebih sering melatih siswa dengan kegiatan penemuan, walau dalam taraf yang sederhana, dimana siswa nantinya dapat menemukan pengetahuan baru, memperoleh konsep dan keterampilan, sehingga siswa berhasil atau mampu memecahkan masalah-masalah yang dihadapinya; 3) Perlu adanya penelitian yang lebih lanjut, karena hasil penelitian ini hanya dilakukan di SMK Negeri 1 Narmada tahun pelajaran 2016-2017.

\section{UCAPAN TERIMAKASIH}

Terima kasih penulis sampaikan kepada Kepala Sekolah SMKN 1 Narmada yang telah mendukung kegiatan penelitian ini sehingga bisa selesai tepat pada waktunya.

\section{DAFTAR RUJUKAN}

Arends, Richard. (1977). Classroom instruction and management. New York: Mc.GrawHill Companies, inc.

Arifin, Mulyati. (1995). Pengembangan program pengajaran bidang studi IPA. Surabaya: Airlangga University Press.

Arikunto, Suharsimi. (2007). Penelitian Tindakan Kelas. Jakarta: PT.Bumi Aksara.

Barnett, A.R. (1980). Intermediate Algebra : Structure and Use. New York: Mc. Graw Hill Companies

Dahar, Ratna Willis. (1989). Teori teori belajar. Jakarta: Erlangga

(2007). Penelitian Tindakan Kelas. Jakarta: PT.Bumi Aksara

Depdikbud. (1993). Kurikulum sekolah menengah umum dan garis garis besar program pengajaran (GBPP) mata pelajaran IPA Fisika. Jakarta: Depdikbud.

Depdiknas RI. (2004). Undang Undang No 20 tentang sistem pendidikan nasional (SISDIKNAS). Jakarta: Depdiknas. 2006. Kurikulum 2006. Jakarta : Depdiknas

Dahar, Ratna Wilis. (1988). Teori-teori Belajar. Jakarta: Dirjen Dikti P2LPTK Depdikbud.

Dimyati \& Mudjiono. (2002). Belajar dan pembelajaran. Jakarta: Rineka Cipta

Djamarah \& Zein. (1994). Dasar-Dasar Evaluasi Pendidikan. Bumi Aksara, Jakarta.

Djamarah \& Syaiful Bahri dkk. (2002). Strategi Belajar Mengajar. Jakarta: Rineka Cipta.

Hudojo, H. (1988). Mengajar Belajar IPA Fisika. Jakarta: Dirjen Dikti P2LPTK Depdikbud.

Oemar, Hamalik. (2001). Proses Belajar Mengajar. Jakarta: PT Bumi Aksara

Sardiman, A. M. (2001). Interaksi dan Motivasi Belajar Mengajar. Jakarta: PT Rajagrasindo Persada.

Slavin, S.E. (1997). Educational Psychology. Theory Into Practices. Fifth Edition. Boston : Allyn Bacon Publishers.

Sitorus., M. (1995). Panduan Belajar IPA Fisika SMA. Jakarta: CV Erlangga.

Soedjadi. (1991). Evaluasi hasil belajar dalam rangka upaya peningkatan mutu pendidikan, Media pendidikan IPA Fisika No 1 tahun 1 Surabaya: IKIP Surabaya.

Soedjadi, R. (2000). Kiat Pendidikan IPA Fisika di Indonesia. Jakarta: Depdikbud.

Suparno, P. (1997). Filsafat Konstruktivisme Dalam Pendidikan. Yogyakarta: Kanisius.

Slameto. (2003). Belajar dan Faktor-faktor Yang Mempengaruhinya. Jakarta: Rineka Cipta.

Sudjana. (1998). Dasar-Dasar Proses Belajar Mengajar. Bandung: Sinar Barn Algesindo. 